\title{
The Beatings Will Continue Until Morale Improves
}

\author{
Mark P. Worrell
}

The sociological absolute is society in general, but the problem of absolute sociology is society's concept of itself, i.e., the dialectic of dialectics, the syllogism of syllogisms, the consciousness of consciousnesses, or the "triangle of triangles" (Rosenkranz [1844] 2002). The universal point of view toward facts and things is no longer fashionable but, as H. G. Wells says, "it is no more pretentious to work upon the whole of life than upon parts and aspects ..." (1928: 7). Wells is also correct that, in itself, no idea is inherently more valuable than any other; just as there is no such thing as value per se (Adorno [1975] 2000: 41), and just as things in themselves are not actually capital (Marx [1867] 1976: 975), it is not until ideas are related (positively or negatively) that a sense of scale and value are registered.

To speak of the Idea of something in the Hegelian sense presumes a victory of sorts (or at least the anticipation of a universal achievement) but society is never an empirically unified thing, and, if anything, it appears to be sliding into an abyss. But integration and wholeness are meaningless without disintegration and partitions. Society, by its very nature as a moral being with its own autonomy over and above the life of individuals, "cannot be assembled all the time" and most of the time it exists as a memory in a dispersed state of semi-profanity (Durkheim [1912] 1915: 391). Nonetheless, because the current phase of universal profanation seems interminable, pessimists would be justified in assuming that teleological activity, if there ever was such a thing, has fallen short. Society is definitely not as it should be, and the persistent defects and backslidings have left many writers today unsure whether 'society' even exists as anything more than an empty signifier; some professional negationists have even joined the ranks of the intellectually departed by embracing, in one form or another, reductionism or transcendentalism. But the negation of Society only amounts to a capitulation to bourgeois nominalism and assists in keeping repressed that which has only sunken into unconsciousness (cf. Durkheim [1912] 1915: 387).

We know for a fact that the negative (bad) absolute of capitalism exists as an autonomous and determining necessity; otherwise commodities could not even circulate (Marx [1867] 1976: 146). We also know that the social domain is one of moral polarities and where there is a negative there must necessarily exist a corresponding positivity. The profane is diametrically opposed, even absolutely, to the sacred but the sacred is characterized by the polar oppositions of purities and impurities. For this reason, Moret and Davy say that not every "sacred principle is a social principle" ([1926] 1970: 52). Indeed, some sacred principles (the impure or negative) are essentially anti-social (e.g., magic, the pursuit of the unlimited, rugged individualism, and so on). Therefore, if the negative absolute exists, as it obviously does, the positive absolute also exists, sunken in the spiritual underground where concepts have their relations dissolved (Worrell 2019).

As a negative absolute, the capitalist 'superstructure' is a nebula of sacred powers but these forces are anti-social in nature; the reason deployed by capital is not merely a 'technical rationality' but an actual anti-reason. We know anti-reason as hyper-rationality, e.g., antisemitic conspiracies and mythologies that fetishize and preserve the rule of capital (Sartre, in Wilson 1982: 604; see also Massing 1949: 13; Worrell 2017; Worrell 2008) as well as hypo-rationality of the abstract schematics of garden-variety prejudices, common sense, and folk wisdom, etc. Therefore, within the negativity of anti-reason that separates and breaks relations (e.g., keeping white free of brown contamination), there is a 'positivity' that seeks to recombine elements in perverse forms (e.g., everything enveloped by the signifier of 'the 
Jew' in deranged conspiracies). The value dimension under capital suffers twists and turns just as any other moral substance does.

One could argue that exchange-value is not directly the enemy of society and is not necessarily an abuse of reason, but the drive for the accumulation of surplus value (underpinned by surplus or excess labor) is the negation of human values. The drive for accumulating surplus value harbors a self-defeating logic of self-delusion, hauntings, and concrete liquidations (Szrot, this volume; Worrell 2009). If money is dead people, the imperative to make and accumulate as much as possible (the capitalist ideal) is necrophilia in almost ideal-typical purity. The billionaire stands atop a mountain of corpses. The pursuit of surplus value, or 'Value' (as if there is now only one worthy of the designation) devalues the remainder of ideals and what should be a system of self-limiting and self-containing forces devolves into an energetic and morbid whirlpool of destruction (Durkheim [1912] 1915: 233). But if the negative seems to have the upper hand, surrounded as we are on all sides by death and disintegration, it might very well be that the enemies of society are unintentionally engaged in actions that raise positivity into the sphere of conscious reflection. The bad and the wrong keep us in myriad chains, but the effects of terror and repression are simultaneously causes of their own energies that mobilize populations around the values of freedom, general welfare, democracy, and peace, etc.

It is often the case that the enemy of $\mathrm{X}$ (let us call it the $-\mathrm{X}$ ) is itself negated by the compression effect that arises from its own propagation and multiplication. This presupposes that the negative cannot only negate itself but that it contains some positive element(s) and this is hard to swallow after the horrors of the 20th Century. It seems impossible that a nightmare can embody reason. Where is the reason, for example, in the Holocaust or the Sandy Hook massacre? The slaughter of children and the concept of 'reason' cannot make contact without disgust. The common solution is not to search for the reason 'in' a thing but, rather, the reason 'for' the thing. But Hegel says that a real dialectical method develops the reason within the thing, not by attributing an external, subjective reason to it, but developing the actual, inner kernel residing within the thing ([1821] 1991: 60). But this inner kernel is not reason in its positive mode. We arrive now at the realization that the negative and positive absolutes are not two separate things but two dimensions of one absolute. Reason is evil (anti-reason) where the actualization of the Idea has been perverted and we are led to the conclusion that the beatings will continue until morale improves. Reason and evil are inseparable; one need only read Goethe's Faust to see that the only character in the story with reason on his side is Mephistopheles (Dahms, this volume). The devil in Faust is not only the spirit of negation but also the voice of reason.

It is possible to fight fire with fire, bullets with bullets, and demons with demons, but once these dynamics get wound up, they know no limit and lead to widespread destruction. That leaves us with the struggle over the negative with the positive and that means knowing the positive within the negative, which seems impossible, though we are all too familiar with the inversion. The negative freedom of individuals under the reign of capital "is the freedom of the void" that, when it becomes active, manifests itself as fanatical destruction, fury, suicide, murder, and terror (Hegel [1821] 1991: 38-39) and these phenomena fall within the odyssey of the concept, not outside of it, and we will make no headway until we embark on discovering the ideas and causes for which people are killing and dying for (Hegel [1821] 1991: 102).

The easiest rationalization is the one that individuates the problem, avoiding the social causes, through psychological reduction and devaluations. Every day, at least one mass shooting is rationalized with the magic phrase "mental health issues." With Durkheim, the solution lies in the direction of grasping that what is abnormal and morbid are only exaggerations of what is considered normal and healthy. This insight is the most difficult to hold to consistently: the virtuous and the vicious are not compartmentally sealed off from one another but exist on a continuum and separated analytically by degrees. As Leonard Nelson once said, "good is the evil we choose to ignore" ([1917] 1957: 90) and, by extension, the evil is merely the good we cannot get enough of. Disease is inseparable from health and life is meaningless without death. With that being said, however, those that would promote the health of society over egoism and greed themselves prohibit the critique of the sacred principle of the modern system by normalizing the predication of capitalism with the sign of 'society.' We know from Hegel that the predicate provides what is essential in this relation between two self-subsisting totalities ([1812] 1969: 624-25) and that capitalism is essentially anti-social. Anti-capitalism is the way back toward real society but the unpleasant truth about American politics is that it is defined and wholly dominated by a one-party system consisting of two wings, both capitalist, and while Red and Blue politicians may personally dislike one another, they are nonetheless business partners and their collaborations are, if not devoid of animosity, still necessary and destructive to democracy. Whatever "progressive" 
elements one might find in the party system are easily contained by capital and exhausted in populist miasmas.

Dialectical necessity has been penetrated by a more powerful necessity of a different species, from another domain of life, that has diverted the course of Spirit away from the goal of conceptual, rational unification. Concreteness is misplaced, and mimesis devolves from social emulation into imitations (Bechtold, this volume). For this reason, it appears that necessity has given way to pure contingency, but where we can still speak of causes and effects there is still the inevitable and the predetermined, at least in a 'subterranean' sense. Where there should be society and reason, what Durkheim calls the "consciousness of the whole" (1961: 277) we instead have capitalism (anti-society) and instrumental rationality (Bechtold, this volume) that breaks the whole down into a negative mechanical totality and further into disjointed abstractions. Yet, even though the positive concrete universal has never realized itself in a permanent condition, it nonetheless exists at least as a concept in a kind of 'fourth spatial dimension' (to appropriate an image from Mauss). All the same, even anti-society is, in its own way, still a social form in the same way that anti-capitalism has so far inclined towards capitalism. It should come as no surprise when altruism turns into egoism, yesterday's communists are today's investors, critical academics dream of equity prices, good becomes evil, or magenta chaos delivers us to the threshold of umber fate. These kinds of transpositions are really inevitable in a world of moral polarities. Still, if anti-society is a kind of society (defective, abstract, evil) it nonetheless possesses all the resources needed to resume its conceptual odyssey. We do not have to wait for something extra or a supplement to reorganize the thing.

If the building of a new city in a waste land is attended with difficulties, yet there is no shortage of materials; but the abundance of materials presents all the more obstacles of another kind when the task is to remodel an ancient city, solidly built, and maintained in continuous possession and occupation. Among other things one must resolve to make no use at all of much material that has hitherto been highly esteemed (Hegel [1812] 1969: 575).

The fact that society is a conceptual being (Durkheim [1912] 1915: 386) has been lost to generations of sociologists who have for the most part abandoned or misinterpreted their classical roots (Smith, this volume). Most self-professed 'dialectical materialists' oscillate between ordinary materialism and transcendental idealism. Sociologists have renounced concepts for variables, have given up explaining the complex through the complex (Durkheim 1974: 29), and chased titles and prizes by emulating the methods of the physical sciences. The techniques seem objective, but the results are purely subjective (Adorno 1976: 72). Instead of relations and dialectical matrices, we see only individuals, brains, descriptions, and the dipping of sticks into prejudice. Ipso facto, it is refreshing to see the old concept of alienation approached in a new way, i.e., from the standpoint of the logical moments of the syllogism (Altamura, this volume), which might sound quaint, but what this really means is that dialectics or the dialectical possess a unified method and a precise structure beyond academic jargon.

It is certainly true that the only active elements in society are individuals (Durkheim [1897] 1951: 310; Durkheim [1912] 1915: 386; Hegel [1807] 1967: 160). In fact, everything is an individual (even the last of the Scholastics admitted this much) but the decisive fact is how individuals logically relate to one another as well as their institutional functions. Even an individual work of art that is self-contained, closed, and inseparable from its cultural horizon (Bechtold, this volume) has other potential functions both particular and universal, and, in relation to the psyche, as Altamura (this volume) reinforces, it is social organization and collective consciousness that determines the structure and the disposition of the individual mind. Anywhere we find an actual individual of sociological importance we are interested in its singularity rather than its subjective infinity.

The 'singular' is not what it is commonly imagined to be but the moment where a plenitude has been sacrificed for the sake of a social function, or, lacking subordination to a concrete universal, submission to the facts of the master (Cassano, this volume). Put simply, piety is rewarded, and voluntary integration is a sign of credibility (Smith, this volume). Being a function lacks the kind of glamour we seek in the bourgeois hologram (Bageant 2007) but being a function means being a fact (Worrell 2018) and while social facts in our world are not as they should be, fraught with contradictions, they are nonetheless essential moments of teleological activity — as such, if one fantasizes about Radical Transformation ${ }^{\mathrm{TM}}$ without going through the facts, one will be forever disappointed. The road to heaven runs through hell and we will need facts in the future even as we are restrained by them — this is especially pertinent when one dreams of the authority of democracy or the authority of positive freedom; there is no such thing as society without the facticity of the social (see Feldmann, this volume). I suspect that if we did arrive at a world of general democracy, we would want to not only preserve the facticity and authority of democracy but make it absolute and inviolable. And, admittedly, the facts of bourgeois society have not precluded the enjoyment 
of genuine, creative individuality and concrete personality for some, even as most are reduced to one-sided beings (subjects) pushed around by impersonal forces and alien desires; the reigning spirit of individualism leads people away from actual individuality and into the waiting arms of heteronomy.

Apropos the process of mono-valuation and the drive for infinite accumulation people are invited to imbibe in the spirits of limitlessness and hyper-individualism, compressed into the negative unity of infinity disease (Durkheim [1897] 1951: 287; Altamura, this volume; Worrell 2015; 2018; 2019). When one stops to question the wisdom of blindly pursuing an alien goal the subject is beset with guilt for lack of faith (Szrot, this volume). Insofar as the invitations are accepted, society, like any 'being,' begins to question the value of existence: to be, or not to be? The negative absolute of the modern world is an autonomous subject that bends the wills of individuals to suit its own fancy; it even pleasures itself for no other reason than for its own self-enjoyment. Just as positive society lives on sacrifices, negative society runs on not only partial death but total and mass death. We have lost sight of the fact that collective representations were born from ritual ecstasy and the frenzied mayhem of self-destructive acts that often teetered on the edge of death (Krier, this volume). Collective representations are born in blood, fire, beatings, lacerations, and excruciating pain that mundane life does not engender. Every explosive but futile act of destruction is, in a way, an attempt to recreate the fury of the rite that generates the energy of the objective social phantom but, ironically, functions to preserve the abstractions and dysfunctions of the prevailing negativity. As capitalism 'works' for fewer and fewer people, with whole classes falling under the wheels of the planetary juggernaut, the estranged and the deranged act out. Their acting out is inspired by the very thing that hates them and that directs their animosity toward substitute targets and scapegoats.

Every moment of every single day, subjects are communicated to in positive and negative tones (Durkheim [1912] 1915: 242). Demands are conveyed through averted eyes, slammed doors, dismissals, rejections, slights, insults, silence, broken promises, the lure of fame, the promise of wealth, impossible dreams, insatiable desires, unrestrained fantasies, holy allegiances, sanguine passions, revenge in the name of justice, blocked endeavors, the impenetrable wall of destiny, and 1001 other things — not least of which is the fate of being struck down by gainful employment and having the means to transform the means into ends. In the ups and downs, augmentations and negations of emotional life, most people (more or less) manage to actively (see Feldmann, this volume) harmonize the pluses and minuses and keep their chins up as they navigate daily routines. They suffer the divisions of alienation but enjoy the reflected multiplications, summon enough courage to temper their self-destructive impulses, and accept the claim on the part of their superiors that to succeed they should model their thoughts and actions on those that have preceded them through dedication and hard work, i.e., they should identify with their betters and desire what is in reality a constellation of alien desires (Cassano, this volume). Never mind that 'dedication' and 'hard work' are all too frequently mere euphemisms for luck and random connections. But the moral and immoral athletes among us cannot be fooled. They take things from another point of view and to extremes.

When we look back on 2019 we will find that something like 1.5 million people in America will have attempted suicide and that, give or take, 50,000 people will succeed in taking their own lives. The individuals themselves are not predestined to destroy themselves but the fact that more than one million people will try actually is predestined (Durkheim [1897] 1951: 325). Suicide is a conscious act, of that, there is little doubt but the social causes that drive individuals to dispose of themselves operate in an almost completely unconscious way. Social forces are not nonconscious but invisible to the mind. People do not know what forces are and, with a nod to Confucius, do not know what they do not know (Thoreau [1854] 1960: 12). Suicide notes are notorious for occluding true motives because the subjects themselves are virtually clueless to the underlying reasons for their symptomatic expressions. But just as consciousness is more complex and multidimensional than mainstream psychology leads us to believe, the unconscious is also more complex. Freud assures us that there is no such thing as a collective unconscious, not because it isn't real, but because the phrase is redundant. "It is not easy to translate the concepts of individual psychology into mass psychology," said Freud, "and I do not think that much is to be gained by introducing the concept of a 'collective' unconscious - the content of the unconscious is collective anyhow, a general possession of mankind" (1939: 170). In short, the unconscious is social from the very beginning.

Given the impoverished state of psychological understanding in critical philosophy and political economy, I think it is important to draw out what goes presupposed in Freud. For example, if one slogs through any of the topflight analyses of Marx's theory of the commodity as a value-bearing object one quickly realizes that even the best writers are utterly lacking in what is meant by the ideal, the mental, and consciousness as they pertain to exchangevalue. They would do well to revisit Freud but also Hegel and, perish the thought, seriously consider Durkheim's 
theory of the sacred. This theoretical synthesis, let us call it the Marxheimian strain of critical theory, embodies an eight-sided psychological matrix: (1) individual / personal; (2) particular / mass / intra-group; (3) universal / social / inter-group; (4) profane / linear understandings; (5) sacred pure / positive; (6) sacred impure / negative; (7) consciousness; and (8) unconsciousness. An absolute psychology would be attuned to the interpenetrations of all eight dimensions.

It is not possible to grasp the logic of capital and negate the accumulation of surplus value until critique situates Value within the realm of the sacred and as it refracts through the various dimensions and spheres of the absolute psychological matrix. Value is not a category of the understanding restricted to the domain of political economy but is an ultramundane or 'otherworldly' principle (Smith 1988). If 'the economy' was a rational system restricted to the production and distribution of goods and services we could get out of it what we put into it. Further, if class exploitation were merely a problem of simple domination it could never sustain itself continuously. It is a fact that the rewards that accrue to sellers of labor power, in general, are inferior to the quantum of energy expended in the labor process so this inferiority must appear, at least in part, to be valid and fits with the logic of "sacrificial tribute" whereby "they give to the sacred beings a little of what they receive from them, and they receive from them all that they give" (Durkheim [1912] 1915: 383). These "sacred beings" are the avatars or personifications of capital. Marx is correct that having a job means paying to work but modern workers are not just 'talking tools' and do not like to think of themselves much in the degrading terms of 'laborers' or 'workers' and they certainly do not hate the personifications of capital. They may hate the signified component, but they have not connected the signifiers to that substance and, consequently, are of two minds (ambivalent) toward the problem of wealth distribution.

Durkheim is famous for amplifying the antique notion that people are double (Homo duplex, double-minded) but when one wrestles with Suicide one comes to the realization that Durkheim's double is itself doubled, and perhaps even doubled again. If one knows Hegel's weird disjunctive syllogism in the big Logic (or the money-price value form in chapter one of Capital) one gets the impression that we are on some kind of similar ground with Durkheim's moral geometry (Worrell 2019) where the universal is capable of enveloping itself. What we need to know is if it is possible for not only individuals to commit suicide but if a concept is also capable of killing itself, either passively or actively, and, further, if there is life after death for the thing sacrificed.

Hegel famously concludes the Phenomenology at Golgotha, heralding a breakthrough for Spirit. The death of the man was a midway point (Hegel 1988: 463) in the Bildungsroman of the world spirit. However, we also know that every midway point is also an end as well as a beginning or a "sunrise" for a new concept (Hegel [1807] 2008: 731). So here was a man who embodied and gave expression to a new concept and was rewarded for his insight and inspiration with a brutal execution. But we do not need the gospel of Judas (Kasser and Wurst 2007) to see that this execution was just as much a suicide - a premodern version of 'death by cop.' Durkheim might classify the death of Jesus (either as an empirically existing person or as a mythological composite) as an instance of positive, indirect, optional altruistic total self-destruction. Jesus will come to live again as a symbolic force but not until decades later when 'Paul' (the first Christian) is engaged not in the rallying and the organization of the flock but in their persecution. Terror is no day at the beach, but it might contain more than we realize. This death is nothing less than conceptual autocide inflicted upon the positive by the negative. The autocide of the concept born by a charismatic leader functioning as a collective representation seems like a preposterous notion that ought to require a lot of ontological tomfoolery, but, I think if one approaches the suggestion of Absolute self-destruction from the standpoint of a consistent social realism, one that is attuned to the nuances and currents both positive and negative, what seems absurd at first is actually true — not self-evidently true but inevitable if we see our argument through to the end.

Within its contemporary horizon, Golgotha surely appeared to be an impossible beginning to what turned out to be a brilliant career. Few individuals can receive a beating for the ages, die from asphyxiation on a cross, be eaten by birds and dogs, and, within a few centuries, conquer an empire. It is entirely plausible that the successful career of Jesus as a collective representation lies in the sheer brutality of his death recounted in stories, icons, and passion plays. World-conquering gods are not normally born from the humiliating annihilation of their profane shells but the terror visited upon Jesus at the end (also a beginning) is relatable to millions of people and the horror of it can be encapsulated in the term 'sacrifice' apart from any collective ritual reenactments. The Jesus sect was subject to state terror because the conceptual breakthrough was politically unbearable and punishable as a crime. Where one finds the 'criminal' one is sometimes in contact with a 'king' (Foucault 1977: 29; cf. Badiou 2003: 56). Indeed, the execution of a criminal is frequently the terminus for royalty (Freud [1913] 1950: 56). The charisma of crime might 
seem odd but the odyssey of the Idea and the dictatorship of reason (Freud 1939: 146-47) do not involve obedience to tradition and custom but disobedience, the demanding of reasons from those in a position of authority, and, quite frequently, unjust and even spectacular punishment.

Universal political oppression can lead to individual depression and the repression of the Idea but it is also possible for repression to lead not to a desublimation per se but what Jean Wahl referred to as a transdescendance (in Sartre 1950: 38-39). As such, as in the case of a charismatic group, repression can be followed by the growth of the positive concept rather than its annihilation. Where there is "terror and compression" (Durkheim [1912] 1915: 256) there is also an automatic counter-current that leads to the transcendence of the concept. A transcendental realm is our nemesis, of that there is no doubt, we do not want more alien gods and the noumenal realm is a pernicious holdover, however, "terror and compression" are simultaneously mechanisms that can reactivate the concept, liberating it from submersion in the unconscious, providing the opportunity for the critical spirit to project the concept back into its rational, positive ground. For example, terror attacks in the US come in external and internal forms that spur connections to politics, race, religion, etc., but, so far, the bourgeoisie have managed to prevent discourse from veering toward the essential concept: capitalism. Since the essential is taboo in America, "terror and compression" will continue unabated until, finally, there are no other dead ends and box canyons for Spirit get lost in. To bring a halt to the self-flagellation of society, the primary role of critical theory today is to connect the explosions of the sacred impure to the concept of capital as a system driven by, and expressing, an abstract, (negative) antireason.

The attainment of the Idea involves, perhaps not necessarily but as a historical possibility, the actualization on a tiny scale, a particularity that knows itself as the whole universe. We see this occur under conditions of tribal disintegration where each clan has universalized itself through retrogression and claimed everything under the moon and stars for itself all the while it is situated alongside other clans operating under the same logic. We find this even today among hyper-specialized academics who, seemingly oblivious to what has gone on around them in other disciplines, seize the Thing for themselves and, with willful ignorance, claim to have grasped some new insight all the while reproducing, in ever-more more flaccid and one-sided forms, ideas that have circulated for generations in other fields. As of 2017, the field of neuropsychology has, I kid you not, finally discovered the Concept. And how many times will social constructionism be reinvented, increasingly subjectivized, before our species goes extinct? While the descending wave is the norm, it also happens that, from time to time, some tiny group of thinkers ensconced in an increasingly stupid world, battle their way to the heights of universal comprehension. Here, a particular group embodies the positive universal and reflects their concept into the void of the reigning, abstract universal sphere. One might think that, in all such cases, the negation of the negation rises like a colossal hammer against innovation, yet, this outcome is not predetermined.

It is not difficult to see in Weber's analysis of musical rationalization a concern for creative epochs when a "striving for expressiveness" can either burst the normative framework of an existing symbolic system or, by contrast, lead in the opposite direction toward a rational enrichment of the symbolic system. In the antiquities, the striving "led to an extreme melodic development which shattered the harmonic elements of the [musical] system" whereas "the same striving led to an entirely different result" in the west to "the development of chordal harmony." The fact that separated the antique from the Occidental outcomes was the institution of polyvocality. "Expressiveness could then follow the path of polyvoiced music" (1958: 65). Polyvocality means that singers are not forced to perform unison within the same octave. The link to callings or vocations and a division of labor are easily connected to the logic of polyvocality. Each pursuing and developing their unique voice contributes to, rather than tarnishes, the collective product. Each voice, here, possesses a "melodic right" while preserving a "uniformity" of "the ensemble" (Weber 1958: 68). And sometimes what appears to be the blow of the mighty hammer of injustice fails not only to squash innovation but to propel it forward to new heights. 


\section{References}

Adorno, Theodor W. [1975] 2000. The Psychological Technique of Martin Luther Thomas. Stanford: Stanford University Press.

Adorno, Theodor W. 1976. "Sociology and Empirical Research." Pp. 68-86 in The Positivist Dispute in German Sociology by Theodor W. Adorno, Hans Albert, Ralf Dahrendorf, Jürgen Habermas, Harald Pilot, and Karl R. Popper. London: Heinemann.

Badiou, Alain. 2003. Saint Paul. Stanford: Stanford University Press.

Durkheim, Emile. [1897] 1951. Suicide, tr. J. Spaulding and G. Simpson. New York: The Free Press.

Durkheim, Emile. [1912] 1915. The Elementary Forms of the Religious Life, tr. Joseph Ward Swain. New York: The Free Press.

Durkheim, Emile. 1961. Moral Education, tr. Everett K. Wilson and Herman Schnurer. Mineola: Dover.

Durkheim, Emile. 1974. Sociology and Philosophy, tr. D. F. Pocock. New York: The Free Press.

Foucault, Michel. 1977. Discipline and Punish. New York: Vintage.

Freud, Sigmund. [1913] 1950. Totem and Taboo. New York: W. W. Norton.

Freud, Sigmund. 1939. Moses and Monotheism. New York: Vintage.

Goethe, J.W. [1808] 1961. Faust, tr. Walter Kaufmann. New York: Anchor Books.

Hegel, G. W. F. [1807] 1967. The Phenomenology of Mind, tr. J. B. Baillie. New York: Harper.

Hegel, G. W. F. [1807] 2008. Phenomenology of Spirit, tr. Terry Pinkard. Unpublished.

Hegel, G. W. F. [1812] 1969. Science of Logic, tr. A. V. Miller. Atlantic Highlands, NJ: Humanities Press International.

Hegel, G. W. F. [1821] 1991. Elements of the Philosophy of Right, tr. H. B. Nisbet. Cambridge: Cambridge University Press.

Hegel, G. W. F. 1988. Lectures on the Philosophy of Religion, abridged. Berkeley: University of California Press.

Kasser, Rudolphe and Gregor Wurst (eds.). 2007. The Gospel of Judas, tr. R. Kasser, M. Meyer, G. Wurst, and F. Gaudard. Washington, DC: National Geographic.

Marx, Karl. [1867] 1976. Capital: A Critique of Political Economy, Vol. 1, tr. Ben Fowkes. New York: Penguin.

Massing, Paul W. 1949. Rehearsal for Destruction. New York: Harper.
Moret, Alexandre and Georges Davy. [1926] 1970. From Tribe to Empire, tr. V. G. Childe. New York: Cooper Square Publishers.

Nelson, Leonard. [1917] 1957. Critique of Practical Reason. Frankfurt: Verlag.

Rosenkranz, Karl. [1844] 2002. “The Full Report of Rosenkranz Concerning the Triangle of Triangles." Pp. 264-269 in Miscellaneous Writings of G. W. F. Hegel, ed. Jon Stewart. Evanston: Northwestern University Press.

Sartre, Jean-Paul. 1950. Baudelaire, tr. Martin Turnell. New York: New Directions.

Smith, David Norman. 1988. "Authorities, Deities, and Commodities: Classical Sociology and the Problem of Domination." Ph.D. dissertation, University of Wisconsin-Madison.

Thoreau, Henry David. [1854] 1960. Walden. New York: New American Library.

Weber, Max. 1946. From Max Weber: Essays in Sociology, eds. Hans H. Gerth and C. Wright Mills. New York: Oxford University Press.

Weber, Max. 1958. The Rational and Social Foundations of Music. Carbondale: Southern Illinois University Press.

Wells, H. G. 1928. The Open Conspiracy. London: Victor Gollancz Ltd.

Wilson, Stephen. 1982. Ideology and Experience. East Brunswick: Associated University Presses.

Worrell, Mark P. 2008. Dialectic of Solidarity: Labor, Antisemitism, and the Frankfurt School. Leiden: Brill.

Worrell, Mark P. 2009. "A Faint Rattling: A Research Note on Marx's Theory of Value." Critical Sociology 35(6): 887-92.

Worrell, Mark P. 2015. "Imperial Homunculi: The Speculative Singularities of American Hegemony." Current Perspectives in Social Theory 33: 217-41.

Worrell, Mark P. 2017. "The Sacred and the Profane in the General Formula for Capital: The Octagonal Structure of the Commodity and Saving Marx's Sociological Realism from Professional Marxology." Pp. 75-119 in The Social Ontology of Capitalism, eds. Dan Krier and Mark P. Worrell. New York: Palgrave Macmillan.

Worrell, Mark P. 2018. The Sociogony. Leiden: Brill.

Worrell, Mark P. 2019. Disintegration. Leiden: Brill. 
